\title{
The Retirement of Kim Robinson
}

by Philip Harvey

hirty years ago the first meetings of theological librarians were held to plan for a professional collective that soon became known as the Australian and New Zealand Theological Library Association. As was only right, one of the people involved in the early planning was the Librarian of Moore College Library in Sydney, Kim Robinson. Kim had been working at Moore since 1974 and became the College librarian in 1975. This meant running both the Library and the College's remarkable archive of historical documents.

To meet Kim means you meet one of his owls, whether as a brooch, pendant, lapel clip, tee-shirt stud, or other attachment. I defy anyone to say they have seen Kim without an owl. Who knows how this owl thing started, but it extended to the Moore College Library, where rows of every kind lined windows and desks, a veritable Parliament of Owls. Entry to the Library was a friendly experience as you were met by dozens of pairs of eyes gazing at you wisely. Colleagues have always known which gift to get for Kim. The only time this benevolence came under threat was when a Malaysian student at Moore complained that such birds should not be kept in a study space; as he explained, in his country owls are bad luck. The owls stayed.

Kim has been engaged in many of the roles of an ANZTLA member. He was the first ANZTLA Newsletter editor. He has been both an indexer and editor of the Australasian Religion Index. He has been Treasurer, but most significantly President of ANZTLA from 1997 to 2001. After the death of the first President, Trevor Zweck, in September of 1996, Wendy Davis enjoyed a brief moment of glory as President before passing the decision on to the vote of the members at the 1997 AGM in Brisbane. Kim came to the position at a time of incipient change in library practice, when technology was taking increasing hold of daily life in the workplace. Kim saw it as necessary to keep focus on the core purpose of ANZTLA as an Association of dedicated libraries and librarians, able to achieve a lot given the limitations of size and resources.

Kim has always been a familiar figure at ANZTLA conferences and we hope that will continue. As well as offering papers Kim has given of his knowledge and experience, both inside and outside the seminar room. This dedication to good works has not precluded him sitting during conference dinners at the 'naughty' table and it was no doubt as a result of mingling freely in such a milieu that he suffered the wine stain incident referred to earlier by Helen Greenwood, and I quote: "I have the distinction of personally baptising his presidential personage with red wine at a memorable Brisbane conference dinner." The garment in question was a magnificently laundered white Indian shirt, the wine a very fine Hunter River vintage selected for the occasion by Carolyn Willadsen's husband. It was perhaps as a result of this incident that Kim kept a watchful eye on carousers at subsequent conference dinners. 
"Thank you Kim for blessing

us with your

presence and your

thoughts. Thank

you for collegiality,

thoughtfulness,

leadership, and

good company."
Curiously, Kim's attendance at conferences seemed always to coincide with some stunning new opera production or theatre milestone in the same city, at the same time. How Kim managed to align all of these cultural events together, like some line-up of the planets, was a source of wonder to those of us who just happened to be around at the same time.

Kim's vast knowledge of theology and related disciplines was used to good effect at Moore College when he took on the role of Senior Librarian Acquisitions. This would have given him much satisfaction in later years. Kim Robinson will retire from work at Moore College on December 31st, 2013. His substantial contribution to ANZTLA was recognised in 2005 when he was made a Life Member of the Association.

Thank you Kim for blessing us with your presence and your thoughts. Thank you for collegiality, thoughtfulness, leadership, and good company. 